Levitsky A. P., Selivanskaya I. A., Markov A. V., Pupin T. I. Biochemical indicators of the organism condition of rats which received high-fat diets with different fatty acid composition. Journal of Education, Health and Sport. 2020;10(5):158-168. eISSN 2391-8306. DOI http://dx.doi.org/10.12775/JEHS.2020.10.05.016

https://apcz.umk.pl/czasopisma/index.php/JEHS/article/view/JEHS.2020.10.05.016

https://zenodo.org/record/3843566

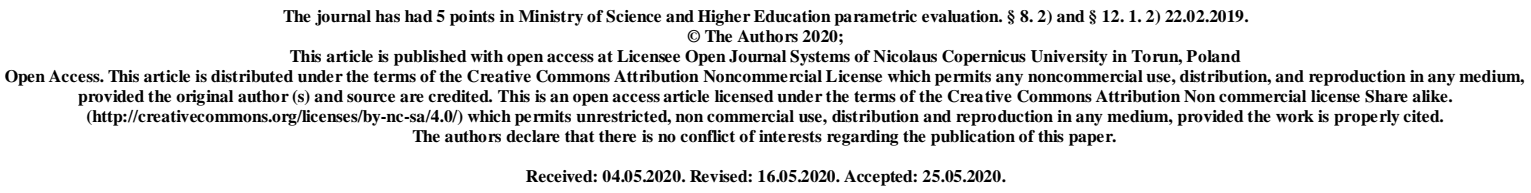

UDK 616.314:664.315

\title{
BIOCHEMICAL INDICATORS OF THE ORGANISM CONDITION OF RATS WHICH RECEIVED HIGH-FAT DIETS WITH DIFFERENT FATTY ACID COMPOSITION
}

\author{
A. P. Levitsky ${ }^{1}$, I. A. Selivanskaya ${ }^{2}$, A. V. Markov³, T. I. Pupin ${ }^{3}$ \\ ${ }^{1}$ Odessa National Academy of Food Technologies \\ ${ }^{2}$ Odessa National Medical University \\ ${ }^{3}$ Lviv National Medical University named after Danylo Galytskij \\ irina.selivanskaya@gmail.com
}

\begin{abstract}
Aim. To determine the effects on the body of high-fat diets (HFD) with different fatty acid composition.

Methods. Used ordinary sunflower, olive, palm and butter, which were introduced into the feed in an amount of $15 \%$. Rats were fed for 41 days. Gum, liver, small intestinal mucosa were isolated and blood serum was obtained, which determined the activity of elastase, ALT and alkaline phosphatase, as well as the content of glucose, triglycerides and cholesterol. The activity of elastase, catalase, urease, lysozyme, and MDA content were determined in tissue homogenates. The API index and the degree of dysbiosis were calculated.
\end{abstract}


Results. In rats treated with HFD, elastase, urease, MDA content increased, but lysozyme and catalase activity decreased in all tissues, the API index also decreased, and the degree of dysbiosis increased significantly. Serum triglycerides and cholesterol increased. Stronger pathological changes occurred in rats treated with palm or butter, and the lowest in rats treated with olive oil.

Conclusion. HFD causes the development of dysbiosis, decreased levels of antioxidant protection and the development of inflammation, more pronounced with the consumption of fats high in palmitic acid.

\section{Key words: high-fat diet; fatty acids; dysbiosis; inflammation; antioxidants.}

\section{Introduction}

One of the factors of inadequate nutrition is a significant increase in fat intake, which causes the development of a number of non-communicable diseases: atherosclerosis, cardiovascular, type 2 diabetes, obesity [1-5]. It is believed that fats with a high content of saturated fatty acids, in particular palmitic acid, play a particularly important role in lipotoxicity [6-9]. There are some restrictions on the amount of consumption and unsaturated fatty acids, especially $\omega-6$ series, such as linoleic, which is the main acid in most vegetable oils [10].

Given the current trends in the development of high-fat diet (HFD), we set ourselves the goal of conducting a comparative study of the impact on the body of different fatty acid composition of dietary fats, which are widely used by the population of Ukraine [11]. This is

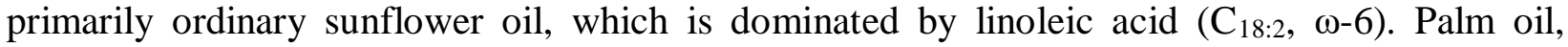
which has recently significantly expanded its use in food as a source of saturated palmitic acid $\left(\mathrm{C}_{16: 0}\right)$. One of the representatives of animal fats is butter, also with a high content of palmitic acid. For comparison, olive oil was chosen, which contains almost $70 \%$ oleic acid $\left(\mathrm{C}_{18: 1}\right)$, which according to many data has a positive effect on the body [12].

\section{Material and research methods}

Characteristics of the fatty acid composition of dietary fats used in the works were presented in our previous work [13]. High-fat diet (HFD) was performed on 40 white Wistar rats (males, 8-9 months, mean live weight $340 \pm 15 \mathrm{~g}$ ), divided into 5 equal groups: 1st, control, received a standard diet of vivarium with a content of $5 \%$ fat. The 2 nd to 5 th groups received a high-fat diet (HFD) with a content of $15 \%$ of the corresponding fat: the 2 nd - ordinary sunflower 
oil, the 3rd - olive oil, the 4th - palm oil and the 5th butter. Edible fats were introduced into the feed instead of $15 \%$ of the grain component.

The duration of feeding was 41 days without restrictions on feed and water consumption. Was determined the increase in live weight during this period.

Euthanasia of animals was performed on the 42nd day of the experiment under thiopental anesthesia $(20 \mathrm{mg} / \mathrm{kg})$ by total bleeding from the heart. The liver, mucous membrane of the small intestine, gums were isolated and blood serum was obtained.

The content of glucose [14], cholesterol [15], triglycerides [15], activity of enzymes were determined in blood serum: elastase [16], alkaline phosphatase (ALPH) [14], alanine aminotransferase (ALT) [14]. Tissue homogenates were used to determine the activity of elastase, catalase [17], urease [18], lysozyme [19] and the content of malonic dialdehyde (MDA) [20].

According to the ratio of catalase activity and MDA content, the antioxidant-prooxidant index of API was calculated [21], and according to the ratio of relative activities of urease and lysozyme, the degree of dysbiosis was calculated according to A. P. Levitsky [22].

All results were subjected to standard statistical processing [23].

\section{Results and discussion}

Table 1 presents the results of determining the biochemical parameters of serum of rats treated with HFD. These data show that all high-fat diets (HFD) increased glucose levels by 12$26 \%$, and most of all butter.

Rats treated with butter had the highest hypertriglyceridemia (3.7 times higher than control). All other HFD increased triglyceride levels by 95-168\%. Significantly (by 49-76\%) in the serum increases the level of total cholesterol in rats treated with HFD.

All HFD increase the activity of elastase in the blood serum, which is a biochemical marker of inflammation [16], with sunflower oil by $21 \%(\mathrm{p}<0.05)$ and palm oil by $31 \%$ $(\mathrm{p}<0.05)$. Olive oil had the least effect on elastase activity $(13 \%, \mathrm{p}>0.1)$.

All rats treated with HFD did not significantly change the levels of two liver markers, namely ALT and ALPH, which may indicate the absence of a negative effect of HFD on the liver in the absence of hepatocytolysis and cholestasis.

In fig. 1 presents the results of determining the activity of elastase in the tissues of rats treated with HFD. These data show that only high palmitic fats (palm oil and butter) significantly 
increase the level of elastase in the gums and liver, which may indicate the development of inflammatory processes in these organs. At the same time, the activity of elastase in the mucous membrane of the small intestine of rats treated with HFD did not differ significantly from the control.

Table 1. The effect of HFD on the biochemical indicators of rat serum $(n=8$ in each group)

\begin{tabular}{|c|l|l|c|c|c|c|c|}
\hline №№ & \multicolumn{1}{|c|}{ Group } & $\begin{array}{c}\text { Glucose, } \\
\mathrm{mmol} / 1\end{array}$ & $\begin{array}{c}\text { Triglycerides, } \\
\mathrm{mmol} / 1\end{array}$ & $\begin{array}{c}\text { Cholesterol, } \\
\mathrm{mmol} / 1\end{array}$ & $\begin{array}{c}\text { Elastase, } \\
\mu \mathrm{kat} / 1\end{array}$ & $\begin{array}{c}\text { ALT, } \\
\mu \mathrm{kat} / \mathrm{l}\end{array}$ & $\begin{array}{c}\text { ALPH, } \\
\mu \mathrm{kat} / \mathrm{l}\end{array}$ \\
\hline 1 & Control & $5,8 \pm 0,2$ & $0,19 \pm 0,02$ & $1,62 \pm 0,24$ & $236 \pm 15$ & $0,47 \pm 0,03$ & $2,90 \pm 0,28$ \\
\hline \multirow{2}{*}{2} & \multirow{2}{*}{ Sunflower oil } & $\begin{array}{c}6,9 \pm 0,2 \\
\mathrm{p}<0,05\end{array}$ & $\begin{array}{c}0,37 \pm 0,05 \\
\mathrm{p}<0,01\end{array}$ & $\begin{array}{c}2,56 \pm 0,17 \\
\mathrm{p}<0,05\end{array}$ & $\begin{array}{c}285 \pm 14 \\
\mathrm{p}<0,05\end{array}$ & $\begin{array}{c}0,42 \pm 0,02 \\
\mathrm{p}>0,05\end{array}$ & $\begin{array}{c}3,08 \pm 0,42 \\
\mathrm{p}>0,3\end{array}$ \\
\hline \multirow{2}{*}{3} & \multirow{2}{*}{ Olive oil } & $\begin{array}{c}6,6 \pm 0,2 \\
\mathrm{p}<0,05\end{array}$ & $\begin{array}{c}0,46 \pm 0,04 \\
\mathrm{p}<0,01\end{array}$ & $\begin{array}{c}2,79 \pm 0,19 \\
\mathrm{p}<0,05\end{array}$ & $\begin{array}{c}268 \pm 23 \\
\mathrm{p}>0,05\end{array}$ & $\begin{array}{c}0,46 \pm 0,04 \\
\mathrm{p}>0,5\end{array}$ & $\begin{array}{c}3,08 \pm 0,27 \\
\mathrm{p}>0,3\end{array}$ \\
\hline \multirow{2}{*}{4} & \multirow{2}{*}{ Palm oil } & $\begin{array}{c}6,5 \pm 0,2 \\
\mathrm{p}<0,05\end{array}$ & $\begin{array}{c}0,51 \pm 0,03 \\
\mathrm{p}<0,01\end{array}$ & $\begin{array}{c}2,85 \pm 0,21 \\
\mathrm{p}<0,05\end{array}$ & $\begin{array}{c}309 \pm 20 \\
\mathrm{p}<0,05\end{array}$ & $\begin{array}{c}0,44 \pm 0,04 \\
\mathrm{p}>0,3\end{array}$ & $\begin{array}{c}3,30 \pm 0,18 \\
\mathrm{p}>0,3\end{array}$ \\
\hline \multirow{2}{*}{5} & \multirow{2}{*}{ Butter } & $\begin{array}{c}7,3 \pm 0,3 \\
\mathrm{p}<0,01\end{array}$ & $\begin{array}{c}0,70 \pm 0,05 \\
\mathrm{p}<0,001\end{array}$ & $\begin{array}{c}2,44 \pm 0,18 \\
\mathrm{p}<0,05\end{array}$ & $\begin{array}{c}282 \pm 21 \\
\mathrm{p}>0,05\end{array}$ & $\begin{array}{c}0,46 \pm 0,04 \\
\mathrm{p}>0,5\end{array}$ & $\begin{array}{c}3,24 \pm 0,33 \\
\mathrm{p}>0,3\end{array}$ \\
\hline
\end{tabular}

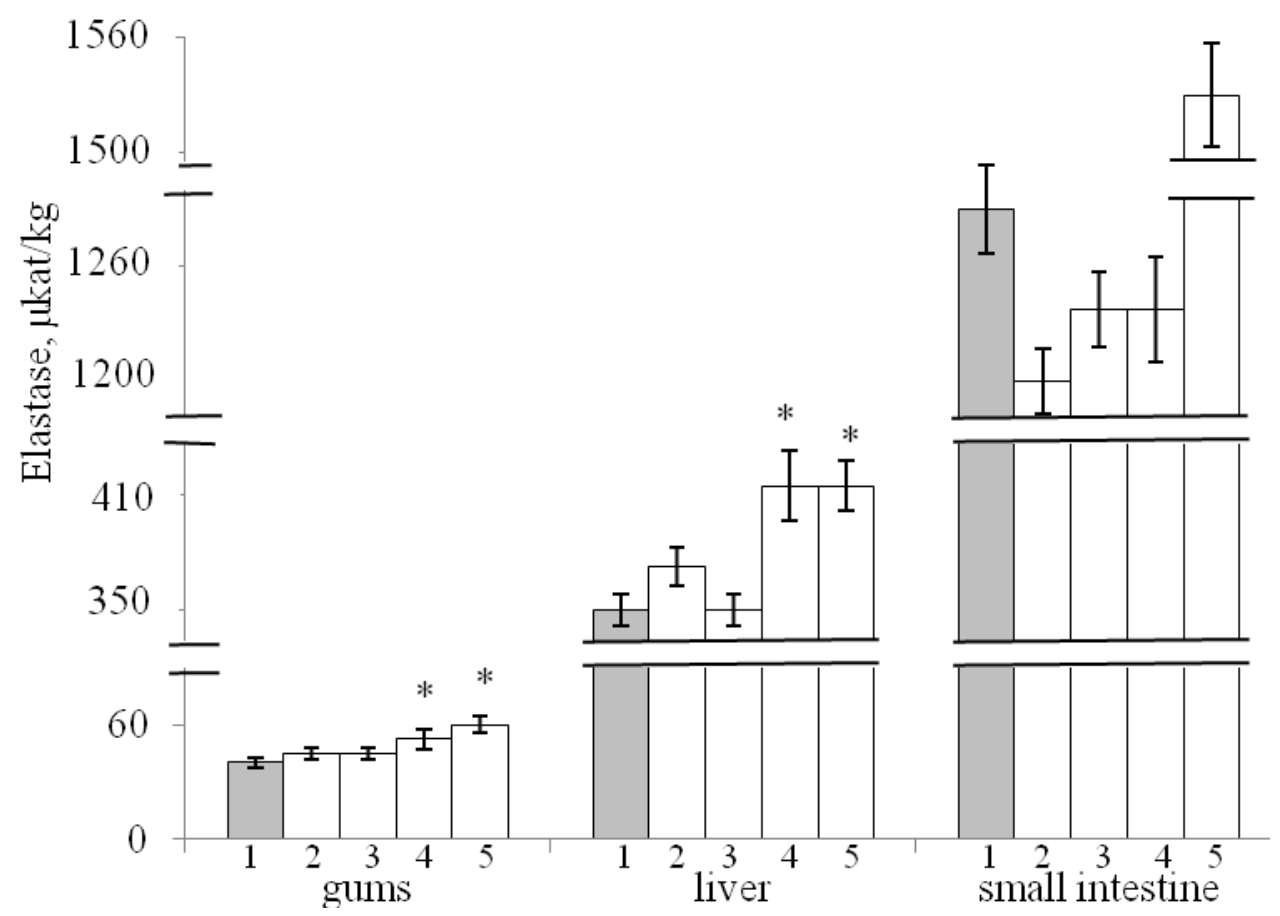

Fig. 1. The effect of HFD on the activity of elastase in the tissues of rats for 41 days ( 1 - control, 2 - sunflower oil, 3 - olive oil, 4 - palm oil, 5 - butter) 
In fig. 2 shows that the second marker of inflammation, MDA, changes little in rats treated with HFD, except for those rats that received butter: in their gums, the MDA content increased by $37 \%(\mathrm{p}<0.05)$.

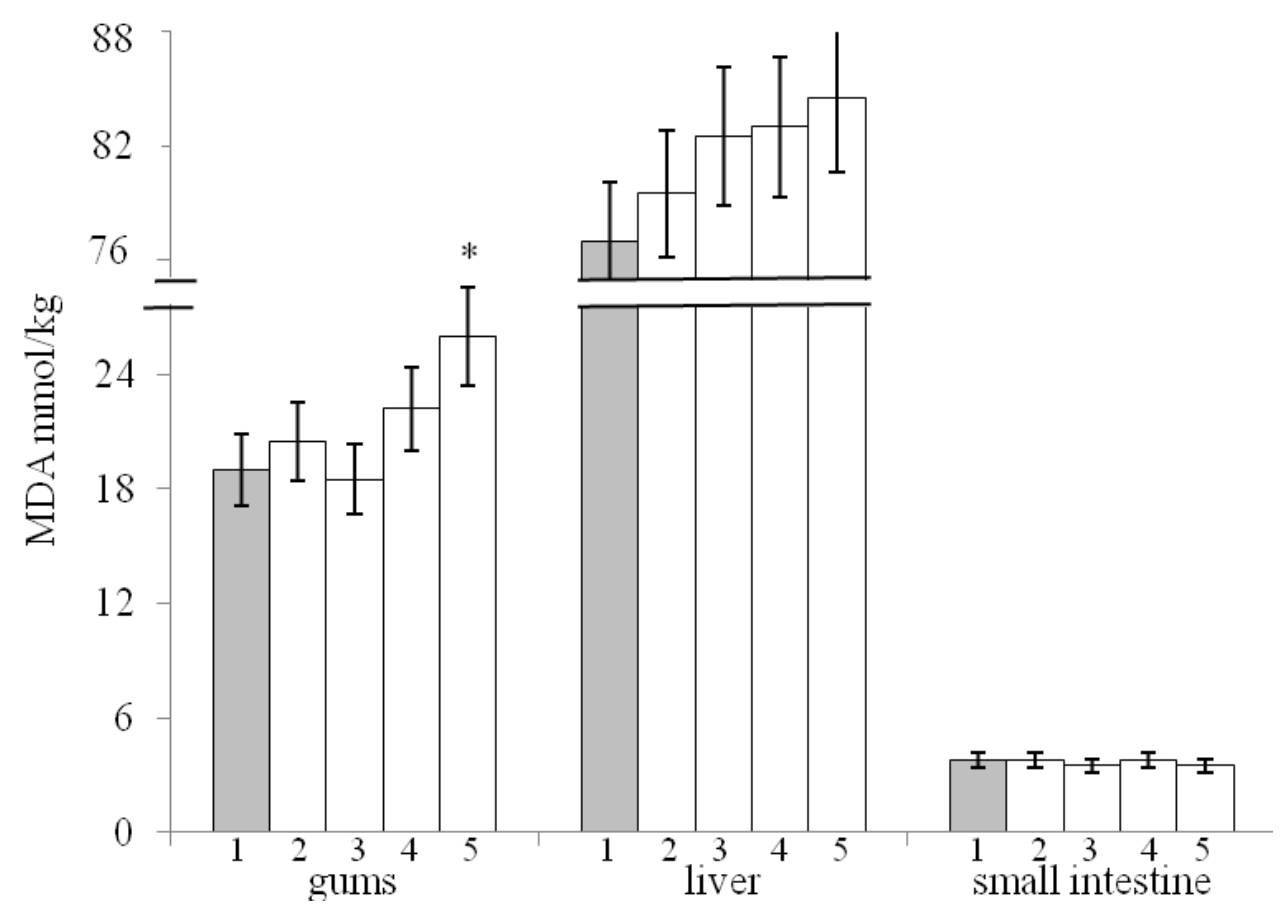

Fig. 2. The effect of HFD on the level of MDA in rat tissues (1-5 - see Fig. 1)

In fig. 3 presents the results of determining the activity of catalase in the tissues of rats treated with HFD. It can be seen that in the organs there is only a tendency to reduce the level of catalase, except for those rats that received palm oil: they have catalase activity decreased significantly by $16.5 \%$ in the gums, and rats that received olive oil: they have a mucous membrane small intestine catalase activity increased by $20 \%(\mathrm{p}<0,05)$.

In fig. 4 presents the results of determining the antioxidant-prooxidant index of API in the tissues of rats treated with HFD. It is seen that in the liver and mucous membrane of the small intestine of rats treated with HFD, the level of API did not change significantly. Only in the gums was it significantly reduced in rats fed a diet of palm oil and butter.

In fig. 5 presents the results of determining the activity of urease, which is an indicator of bacterial contamination. From these data it is seen that the mucosa of the small intestine reacted 
to the greatest extent to HFD, in which the urease level increased 3 times after consumption of olive oil and 6-7 times after consumption of other fats.

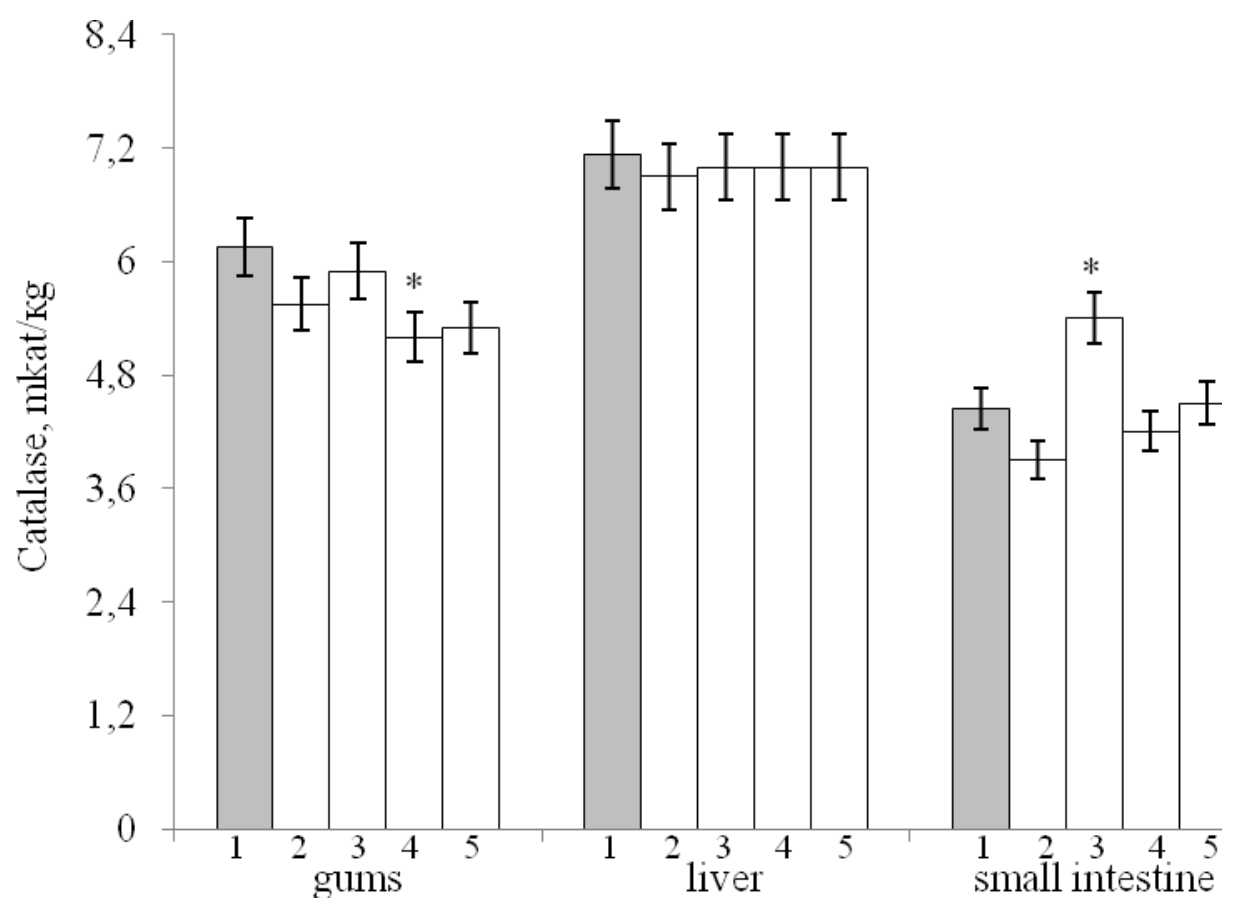

Fig. 3. The effect of HFD on catalase activity in rat tissues (1-5 - see Fig. 1)

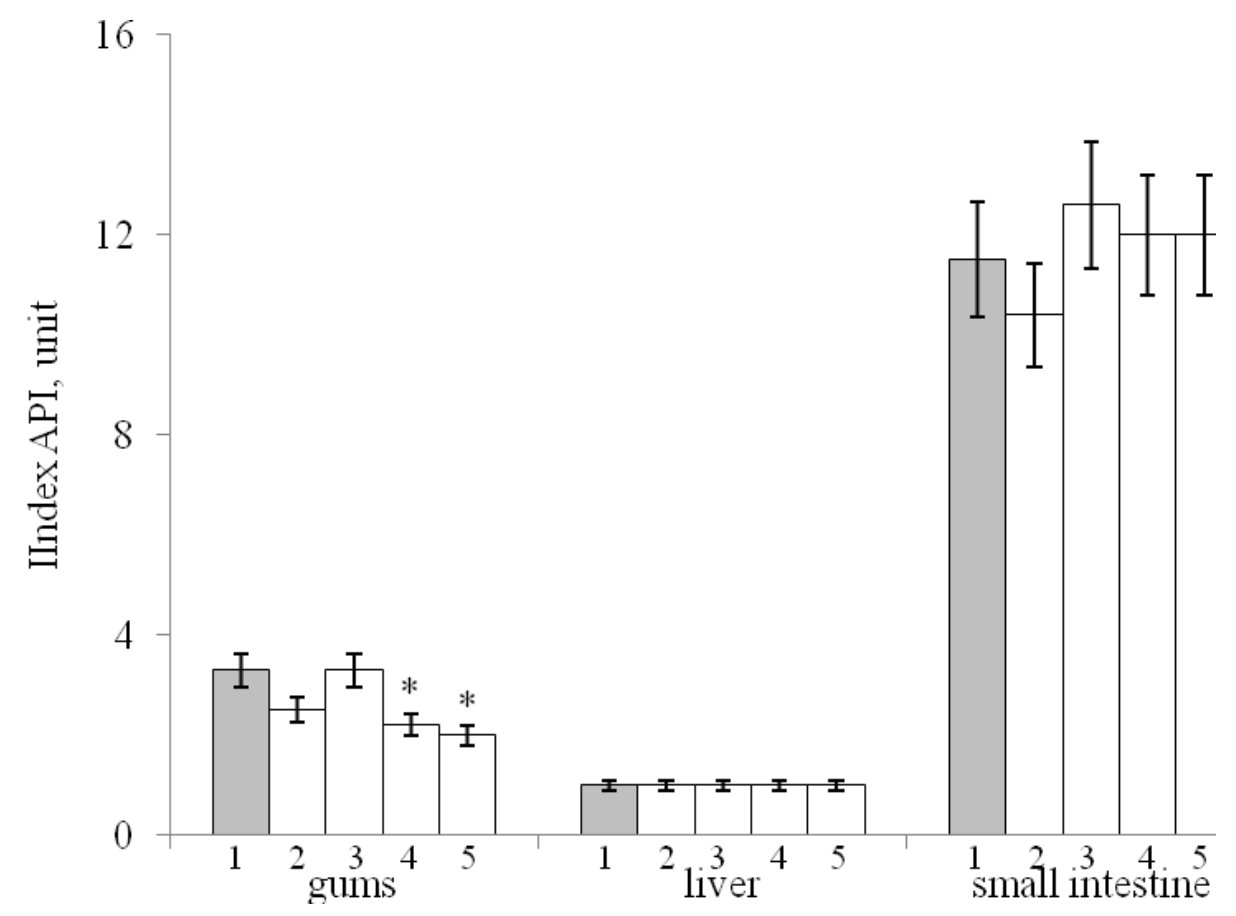

Fig. 4. The effect of HFD on the API index in rat tissues

(1-5 - see Fig. 1) 


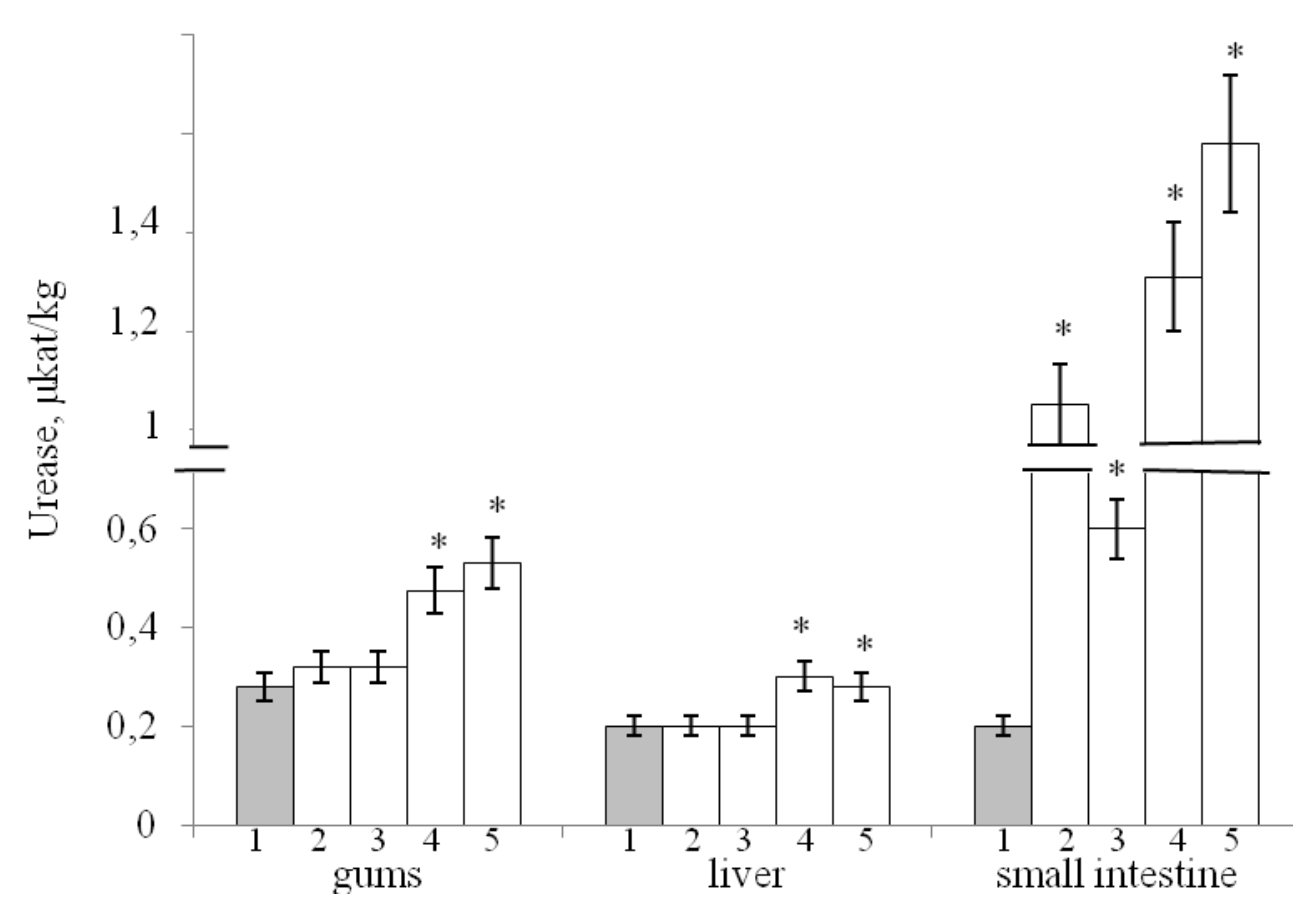

Fig. 5. The effect of HFD on urease activity in rat tissues (1-5 - see Fig. 1)

In the liver and gums, urease activity was significantly increased only in those rats that consumed palm oil and butter.

In fig. 6 shows that, in contrast to urease, lysozyme activity in all tissues decreased, especially in those rats that received HFD with palm oil and butter. In the liver of rats treated with HFD, lysozyme activity was significantly reduced by $34 \%$ (sunflower oil), $38 \%$ (olive oil), $59 \%$ (palm oil) and $71 \%$ (butter). In the gums of rats, lysozyme activity was significantly reduced in rats treated with sunflower oil (21\%), palm oil (39\%) and, especially, butter (73\%). Olive oil also caused a $20 \%$ decrease in lysozyme activity in the gums (however, $\mathrm{p}>0.05$ ).

The degree of dysbiosis in the tissues of rats treated with HFD was calculated from the ratio of the relative activities of urease and lysozyme. The corresponding data are presented in Fig. 7, which shows that HFD in all cases causes the development of dysbiosis. The highest degree of dysbiosis is observed in rats treated with palm oil or butter. Thus, in rats treated with butter, the degree of dysbiosis increased 7 times (gums), 9 times (small intestine) and almost 5 times (liver).

In rats treated with palm oil, the degree of dysbiosis increased 3 times (gums), 10 times (small intestine) and 3.5 times (liver). 


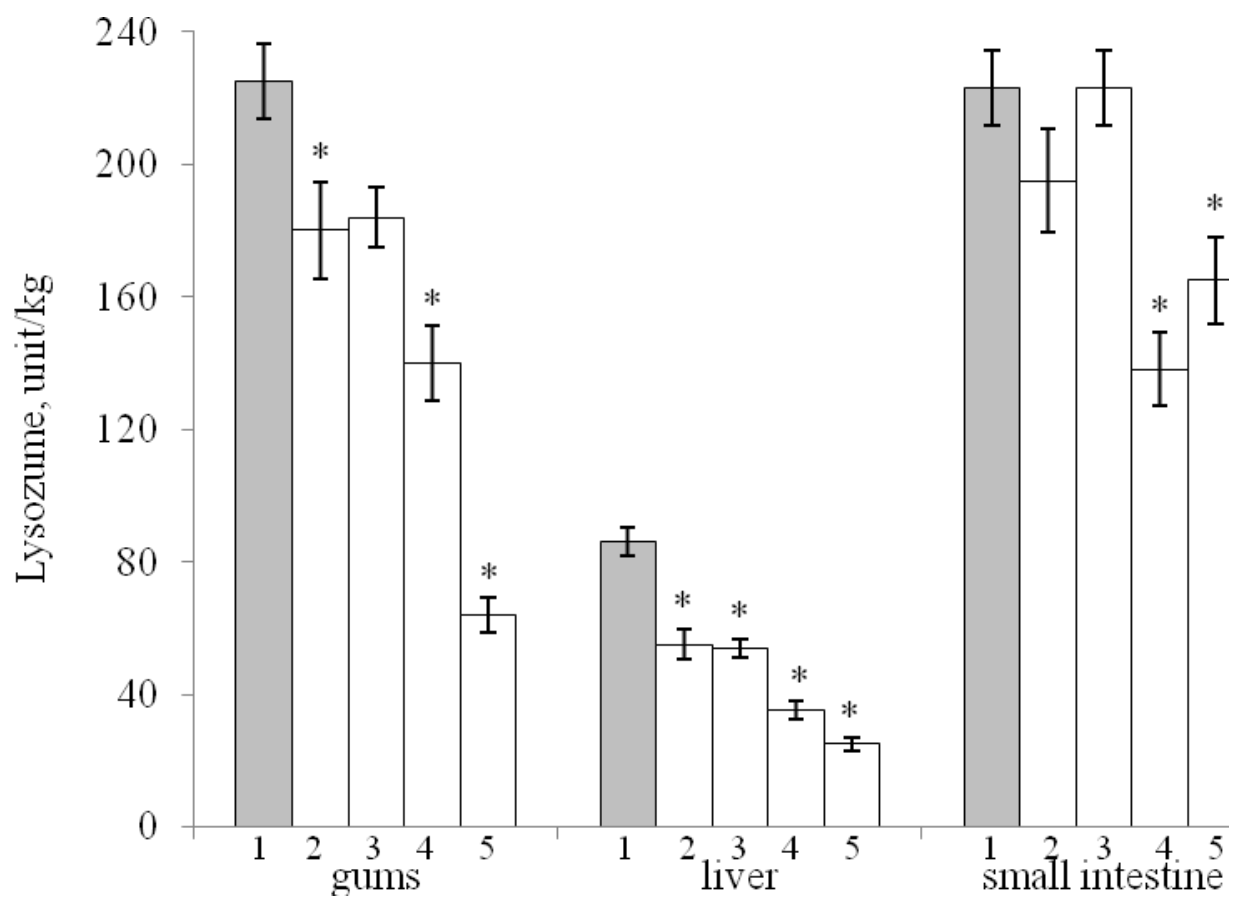

Fig. 6. The effect of HFD on lysozyme activity in rat tissues (1-5 - see Fig. 1)

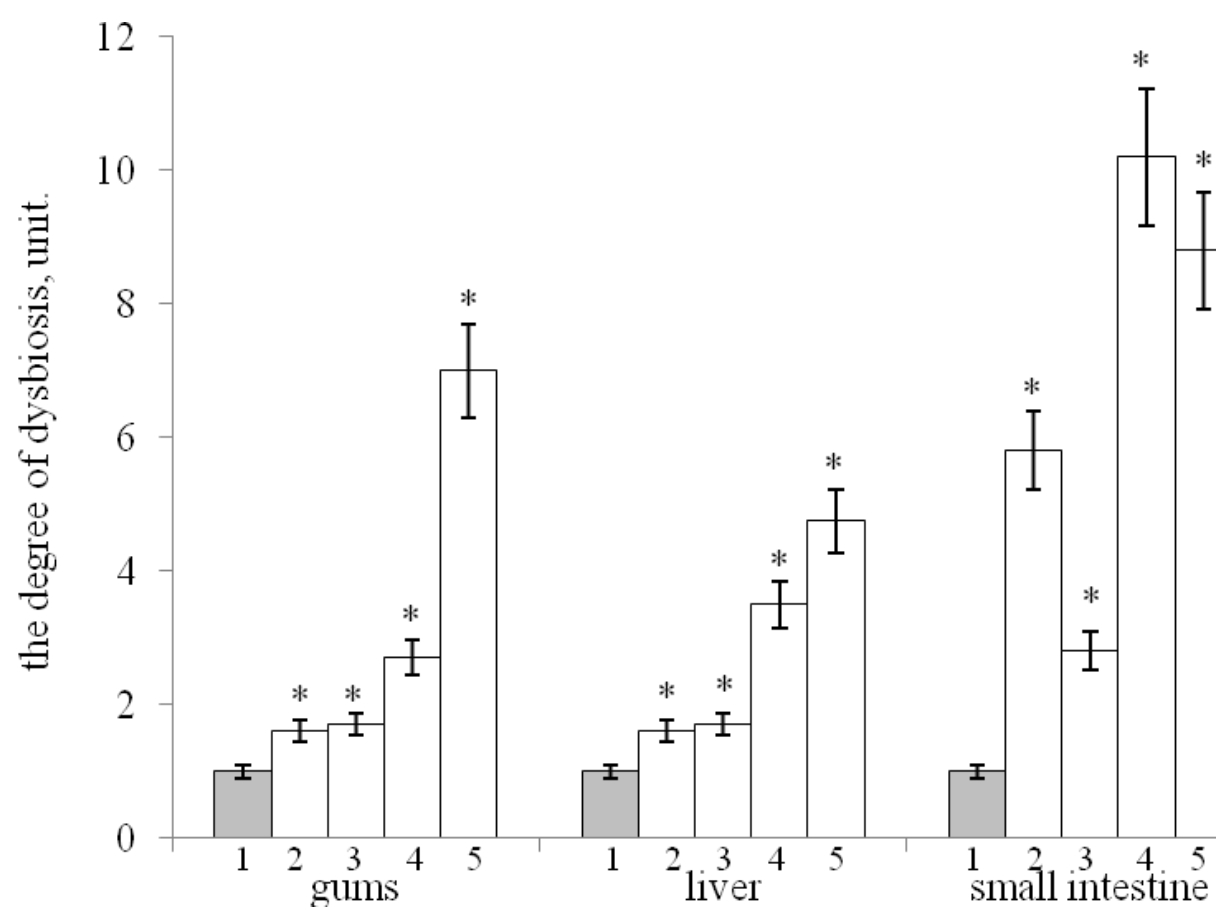

Fig. 7. The effect of HFD on the degree of dysbiosis in rat tissues (1-5 - see Fig. 1) 
If we combine the indicators of increase or decrease in the level of biochemical markers in relation to the control of HFD, the corresponding data presented in table 2 show that the activity of elastase on average in all HFD gives a significant increase in the gums and liver except the small intestine, which increased the activity of elastase only butter. The same applies to the second marker of inflammation - MDA.

Table 2. Influence of HFD average deviations in $\%$ from control of biochemical markers of rats

\begin{tabular}{|c|c|c|c|}
\hline \multirow{2}{*}{ Indicators } & \multicolumn{3}{|c|}{$\%$ deviations from control } \\
\hline & gums & liver & small intestine \\
\hline \multicolumn{4}{|c|}{ A. Biochemical markers of inflammation } \\
\hline Elastase & $+33,9$ & $+10,6$ & $+1,3$ \\
\hline MDA & $+15,5$ & $+7,1$ & $-0,5$ \\
\hline \multicolumn{4}{|c|}{ B. Indicators of the antioxidant system } \\
\hline Catalase & $-12,5$ & $-2,1$ & $-3,0$ \\
\hline API & $-21,0$ & $-8,1$ & $-5,7$ \\
\hline \multicolumn{4}{|l|}{ C. Dysbiotic indicators } \\
\hline Urease & $+211,5$ & $+20,2$ & $+383,3$ \\
\hline Lysozyme & $-39,9$ & $-50,3$ & $-19,3$ \\
\hline The degree of dysbiosis & $+243,7$ & $+184,5$ & $+617,5$ \\
\hline
\end{tabular}

Indicators of antioxidant protection (catalase and API) in all tissues of rats treated with HFD show a significant decrease, especially in the gums.

Indicators of dysbiosis, namely urease, lysozyme and degree of dysbiosis, were the most sensitive to HFD. In all tissues, the consumption of fats significantly increased the activity of urease, which indicated bacterial contamination and significantly reduced the activity of lysozyme. As a result, we have a significant increase in the degree of dysbiosis, which is consistent with our previous data $[8,13]$.

\section{Conclusions}

1. High-fat diet (HFD) causes the development of dysbiosis in the body by reducing the level of nonspecific immunity.

2. HFD reduces the level of antioxidant protection in all tissues.

3. HFD causes the development of inflammatory-dystrophic process in the liver and gums.

4. HFD leads to an increase in serum triglycerides and cholesterol. 
5. Of all the studied fats, the greatest pathological effects on the organism have fats with a high content of palmitic acid (butter and palm oil), and the least - olive oil.

\section{References}

1. Levitsky AP. The pathophysiology of high-fat diet and ways to prevent its complications. Bulletin of XVII readings named after V. V. Podvysotsky, May 24-25, Odessa, 2018: 120-124. (in Russian)

2. Clauss SB, Kwiterovich PO. Long-term safety and efficacy of low-fat diets in children and adolescents. Minerva pediat. 2002; 54(4): 305-313.

3. Cai X, Haleem R, Oram S [and others]. High fat diet increases the weight of rat ventral prostate. Prostate. $2001 ;$ 49(1): 1-8.

4. Kravchenko LV, Aksenov IV, Trusov NV [and others]. The influence of the amount of fat in the diet on the activity of xenobiotic metabolism enzymes and antioxidant protection in rats. Nutrition Issues. 2012; 81(1): 24-29. (in Russian)

5. Gogichadze G, Misavishvili E. Possible interrelation of dietary fats with the process of oncogenesis. Bulletin of the Academy of Sciences of Georgia. Biology Series. 2002; 28(5-6): 519-523 (in Georgian).

6. Titov VN, Rozhkova TA, Amelyushkina VA [and others]. The role of palmitic fatty acid in the initiation of hypertriglyceridemia, hypercholesterolemia, atherosclerosis and atheromatosis. International Medical Journal. 2015; 21(2(82): 5-14. (in Russian)

7. Rachek II, Musienko SI, Le Doux SP [and others]. Palmitate induced mitochondrial deoxyribonucleic acid damage and apoptosis in 16 rat skeletal muscle cells. Endocrinology. 2007; 148(1): 293-299.

8. Levitsky AP, Bocharov AV, Khodakov IV [and others]. Colitis in rats fed high palmitic edible fats. Actual problems of transport medicine. 2019; 3: 120-127. (in Russian)

9. Solinas G, Naugler W, Galimi F [and others]. Saturated fatty acids inhibit induction of insulin gene transcription by INK-mediated phosphorylation of insulin-reception substrates. Proc. Natl. Acad. Sci U. S. A. 2006; 103(04): 16454-16459.

10. Titov VN. Clinical biochemistry of fatty acids, lipids and lipoproteins. M.-Tver: Triad, 2008: 272. (in Russian) 
11. Levitsky AP. The ideal formula of fatty food. Odessa, KP OGT, 2002: 64. (in Russian)

12. Levitsky AP. Olivka: the unique sunflower oil, the analogue to olive oil]. Odessa, KP OGT, 2013: 28. (in Russian)

13. Markov AV. Influence of high-fat diets with different fatty acid composition on rat periodontal condition. Journal Education, Health and Sport. 2017; 7(1): 846-856.

14. Goryachkovsky AM. The clinical biochemistry in laboratorial diagnostics [ $3^{\text {rd }}$ ed.]. Odessa, Ecology, 2005: 616. (in Russian)

15. Tets NU. The encyclopedia of clinical laboratory tests. Moskow, Labinform, 1997: 128, 459-460. (in Russian)

16. Levitsky AP, Stefanov AV. The methods of the determination of the activity of elastase and its inhibitors: method guidelines. Kiev, GFK, 2002:15. (in Russian)

17. Girin SV. The modification of the method of the determination of catalase activity in biological substrates. Laboratory diagnosis. 1999; 4:45-46. (in Russian)

18. Gavrikova LM, Segen IT. Urease activity of oral liquid in patients with acute odontogenic infection of maxillo-facial part. Stomatology. 1996; The extra issue :49-50. (in Russian)

19. Levitsky AP. Lysozyme instead of antibiotics. Odessa, KP OGT, 2005: 74. (in Russian)

20. Stalnaya ID., Garishvili TG. The method of revelation of malonic dialdehyde with thiobarbituric acid. Moskow, Medicine, 1977: 66-68. (in Russian)

21. Levitsky AP, Denga OV, Makarenko OA [and others]. Biochemical markers of inflammation of oral cavity tissue: method guidelines. Odessa, KP OGT, 2010: 16. (in Russian)

22. Levitsky AP, Makarenko OA, Selivanskaya IA. [and others]. Enzymatic methods for determination of oral dysbiosis for screening pro- and prebiotics: method guidelines. Kiev, GFC, 2007: 22. (in Russian)

23. Truhacheva NV. Mathematical Statistics in biomedical research using application package Statistica. Moskow, GJeOTAR-Media, 2012: 379. (in Russian) 